\title{
The Students' Vocabulary Understanding of British and American English
}

\author{
Hermini Parjas *1, Ardhy Supraba ${ }^{2}$ \\ I, 2 Universitas Cokroaminoto Palopo \\ *miniparjas@gmail.com
}

\begin{abstract}
This research aims to find out the students' vocabulary understanding of American English and British English. The population of this research is the seventh semester students of Universitas Cokroaminoto Palopo which consists of three parallel classes. The total population is 120 students in academic year 2018/2019. Cluster random sampling technique is used to determine the sample. This research took one class as sample. The result of this research shows that the students' vocabulary understanding of American and British English is fair. It can be seen by the result of mean score that is 52.67 which is classified into fair.
\end{abstract}

Keywords: vocabulary; students' understanding; American English; British English

\section{Introduction}

English has many varieties in its use in communication. In some continents people use different kinds of English varieties such as Australian English, Ireland English, American English, and British English. Those varieties appeared as there were the different function and speaker of English which related to vocabularies, pronunciation, and grammar. As English is spoken globally, there is a trend of new varieties of English. Somehow, there are varieties that accepted as standard language.

Commonly there are two standard English used in the world. Standard English means English that used widely in formal event. In this case, there are two varieties of languages that considered as Standard English used in the world. They are American and British English. Those varieties of English are used universally in education, mass media, politics, and trade. In fact, there are some differences between American English and British English including vocabulary, spelling, grammar, and pronunciation. These differences can be identified easily for the speakers who used to expose them.

Based on Kachru's circle there are three layers of circle which show the speakers of English. First layer is inner circle that include countries which use English as first language such as USA, Australia, Ireland and some other countries. The second layer is outer circle which include countries that use English as second language. In this layer countries such as Singapore, Malaysia, Philippine, and some countries are included. Thirdly, expanding circle includes countries which use English as foreign language such as China, Japan, Korea, and some other countries. Indeed, Indonesia is included in expanding circle as the status of English is foreign language in Indonesia and it becomes one challenge for the students of English department.

Understanding varieties of Standard English can be very helpful to catch more information on mass media or other source. Beside that knowing varieties of English can improve the 
skills in communicating with other people and of course, knowing those kinds of varieties will open the horizon that language can be varied. However it does not mean that we can use English in our own way of unstructured sentences or wrong pronunciation. American English and British English are mostly used in the world. Therefore we need to know these two varieties of English. Unfortunately, many English speakers may only know one kind of English or cannot differentiate between British English and American English especially related to vocabularies which is one of the important element of a language. Knowing the students' vocabulary understanding of the students can be one reference or feedback for the lecturers to see the flaw side of teaching process and plan the new stage or strategy in teaching English varieties.

\section{Standard English}

There are some criteria for Standard Language; they are authority, language of famous writers, democracy, logic, and language of important people in community. English is a language that used most widely in the world. No one seems to have spent anytime debating whether or not they should broadcast in English. There is a plenty of discussion about what kind of English should be used, of course; but the choice of English in the first place was simply not an issue (Crystal, 2004:84). Based on historical foundation, English had impacted the use of language in the world. It may be one reason why English became global language.

Standard means widely accepted. According to McArthur in Farrel and Martin (2009:2) Standard English is generally considered "the variety most widely accepted, understood, and perhaps valued within an English speaking country". It is related to the correct usage of a language and acceptability in community. Furthermore McArthur in Farrel and Martin (2009:2) stated that Standard English has at least three identifying characteristic. The first, it is easiest to recognize in print because written conventions are similar worldwide. In this case most of books were published and accessed in English. Secondly, it is usually used by news presenter. Mass Medias of world news expose English to convey information. Of course it is one reason why English became standard language. Third, its usage relates to the speaker's social class and education. There is a tendency that certain varieties of English are used in education. Certain varieties of English are limited used in social class of English speakers. Even people can predict the social class of a community by their English used.

Faircluogh in Hickey (5) added that Standard English was regarded as correct English, and other social dialect other social dialects were stigmatized not only in terms of correctness but also in terms which indirectly reflected on the lifestyles, morality and so forth of their speakers, the emergent working class of capitalized society: they were vulgar, slovenly, low, barbarous, and so forth. This case can judge that non-standard English use can reflect the social class of a community. Indeed, a language can show where the speaker's class from. Farrel and Martin (2009:3) clarified that If Standard English is supposed to be an example of only one norm of the English language then the term World Englishes would be the norm that includes all varieties of the language. Standard English refers to a certain variety of English where it is accepted as a standard accent. Standard English concerns vocabulary, spelling and grammar. To clarify Standard English further, General American is mainly associated with Standard English since it is a major accent of the English variety used in the United States. There are some facts related to American English recently. It influences the use of English as American English mostly are mostly used in films, radio, and television. American English is Standard English that is used in the United State. Commonly there are sharply differences of American English and British English, such as spelling, grammar, vocabulary, and pronunciation that can be clearly identified. Those differences appeared based on the historical background. 
World Englishes mostly use American dialect and had exercised greater influence on English in the world (Crystal in Safaa. 2015:10). It means that the variety of American English mostly used on media and information sources all over the world. Even movie and film recently exposed American culture and of course American English variety. Jankonwaki in Safaa (20I5:II) added that American English will be the language spoken in the US with its geographically, politically and economically conditioned characteristics. It ensure that American English will be the world language even though American English was considered less educated, less cultured, less beautiful in British English Totti in Safaa (2015:1I). It is caused by American English accents were changed and influenced by the immigrations of the British and Germanic in the North America.

Furthermore Trudgill and Hanna in Alftberg (2009:4) stated that British English is the standard accent known as RP, normally the variety taught to pupils who are studying English. It means that British English should be one of the priorities taught in schools as British English is the most prestigious variant of English. Furthermore Tottie in Alftberg (2009:4) stated that the text-books are used in schools in many countries in many countries today are still mostly British English-oriented. British English has original and unique accent that is considered as prestigious. The changes of accents, dialects, vocabularies may be caused by the simplified of function in its use in other countries.

Stelzerova (2014:54) investigated about Teaching Differences between British and American English in Lower-Secondary EFL Classes. The result of this research showed that it was necessary to find how differences between British and American English in EFL textbooks. The differences between British and American English should be taught on a regular basic without affecting the lesson plan and might be an enriching animation of the lesson for both teachers and students. It means that teachers need to create material relating to the differences of varieties of English. In higher level of education knowing the students' vocabulary can be helpful to arrange follow-up plan and material for the students.

In other research Safaa (2015:23) investigated British vs American English for University Students Teaching Purposes: The Case of Third-Year EFL Students at Tlemcen University, this research explained that British and American English have variants of English as a whole: the differences do not only affect the pronunciation but also other levels like grammar, writing, semantics and lexica. The students' varieties of English were influenced by the variety that they exposed. It means that finding out the students' variety of English can help the teacher to consider the teaching materials. Furthermore, Biswanger (2008: 43-44) concluded that varieties of English are still not adequately represented in current ELT. It means that varieties of English might be not taught explicitly. The curricula, material, and teacher training program have concerned certain details. Indeed to increase the students' communication skills in the maximum situation as much as possible the students need to encounter varieties of English.

\section{The Differences between American English and British English}

Generally there are some differences between American English and British. Those differences can be identified such as spelling, grammar, vocabularies, and pronunciation. Thus the speakers of English may prefer one variety on their communication based on their exposure of English. If someone used to expose American English he/she may speak in American English and vice versa. It is not a problem for native speakers or second language speakers but of course it will be a problem for English foreign learners. They may have different case in using both of varieties. 
Stelerova (2014:12) stated that if learners study British and American differences, they might simultaneously broaden their social and cultural experience regarding life and institutions of English-Speaking countries. It means that students of English foreign learners should understand that varieties of English do exist and they need to expose them. Related with this the difference of American and British English is one priority of variety that should be learned among students. The basic component should be taught is vocabularies as it may cause misunderstanding. Sartvik and Leech in Stelerova (20I4:I3) added that there are about 4000 different words in American English and British English which some of them known in both countries, but many words are not. This fact is surprising. We consider that English may only have varieties on accent or pronunciation but merely different vocabulary may cause frustrating for the learners on how to use them appropriately that suitable with context. Briefly, the students do need to expose them to understand the appropriate usage in different varieties of language.

That's why English Foreign learners need to understand the vocabularies differences between American English and British English. The same words may have different concept. Here are the common differences between American English and British English.

Spelling

In a few cases, essentially the same word has a different spelling which reflects a different pronunciation. American English uses simplified spelling, such as analize in American English and analise in British English, center and centre, license and licence, color and colour, catalog and catalogue, fulfill and fullfill, anemia and anaemia, and faces and faeces. We can notice them by ize and -ise, -se and -ce, -or and -our, -og and -ogue, -a and -ae, and there are still many differences in spelling between American English and British English.

Vocabulary level

American English and British English significantly have different vocabularies. The same concepts are different words. For example fall and autumn, antenna and aerial, lawyer and solicitor, cookie and biscuit, trunk and boot, resume and curriculum vitae, movie and film, storey and floor, eggplant and aubergin, sweet and candy, and there are still many differences or synonyms of American English and British English.

Grammar level

On grammar level the differences occur on verbs, tenses, adjectives, adverbs and prepositions.

Verbs

In this case American English and British English have differences in using regular and irregular verbs in the past simple tense. American English regular verbs are British English irregular verbs. Here are the examples:

$\begin{array}{ll}\text { AmE } & \text { BrE } \\ \text { awake awaked awaked } & \text { awake awoke awaken } \\ \text { burn burned burned } & \text { burn burnt burnt } \\ \text { dream dreamed dreamed } & \text { dream dreamt dreamt } \\ \text { learn learned learned } & \text { learn learnt learnt } \\ \text { smell smelled smelled } & \text { smelt smelt smelt } \\ \text { spill spilled spilled } & \text { spilt spilt spilt }\end{array}$


spoil spoiled spoiled $\quad$ spoilt spoilt spoilt

The verbs (fit, quit, and wet) are regular in British English but irregular in American

AmE

fit-fit-fit

quite-quite-quite

wet-wet-wet

\section{BrE}

fitted-fitted-fitted

quiet-quietted-quietted

wetted-wetted-wetted

Tenses

Tenses of American English are different from British English on the use of simple past tense and present perfect tense. As example He just arrived and He has just arrived.

Adjective and adverbs

American and British English use of adjectives shows such as systematic variation between the two varieties. Most of differences are as follow:

I) The use of suffix -ed to form adjectival modifiers from nominal. British uses certain forms that American does not, such as booted.

2) Adjectives are freely formed by adding -ish to adjectives, nouns, and few other forms such as cheapish, donnish, fastish (Algeo in Safaa 20l4:20).

3) Adverbs of frequency (generally, never, usually) tend to occur in medial position, such as She usually is at work from nine to five versus She is usually at work from nine to five.

\section{Prepositions}

The use of "on" and "in" preposition between American English and British English are sometimes different. Here are the examples:

AmE

Beckham is on the team

we live on Jaya street

\section{BrE}

Beckham is in the team

we live in Jaya street

\section{Method}

The design of the research was descriptive research which determines and describes the things are. It aims to describe the students' vocabulary understanding of American English and British English in Universitas Cokroaminoto Palopo. The simple calculation was used to determine the students' vocabulary understanding.

This research was conducted in Universitas Cokroaminoto Palopo in September 2018. The population of this research was the seventh semester students in academic year 2018/2019. The total number of the population was 120 students. The seventh semester consisted of three classes. The sample of this research was the students of the seventh semester in academic year 2018/2019. The sample was taken by using cluster random sampling technique. One class was chosen as sample which consisted of 40 students.

To obtain the data, this research used vocabulary test which consisted 60 words. 30 words were American English and 30 words were British English. The students were requested to find the meaning of each word and match American English vocabularies to the synonyms in British English words. The result of the data was used to determine the students' understanding of American English and British English 


\section{Results}

\section{The students' vocabulary understanding of American English and British English}

Table I. The students' score of vocabulary understanding of American and British English.

\begin{tabular}{rrrr}
\hline No & Score & Frequency & Total \\
\hline 1 & 33.3 & $\mathrm{I}$ & 33.3 \\
2 & 36.6 & $\mathrm{I}$ & 36.6 \\
3 & 40.0 & $\mathrm{I}$ & 40.0 \\
4 & 43.3 & 3 & 129.9 \\
5 & 46.6 & 2 & 93.2 \\
6 & 50.0 & 8 & 400.0 \\
7 & 53.3 & 3 & 159.9 \\
8 & 56.6 & 3 & 169.8 \\
9 & 60.0 & 2 & 120.0 \\
10 & 63.3 & 3 & 189.9 \\
11 & 66.6 & 1 & 66.6 \\
12 & 73.3 & 1 & 73.3 \\
13 & 76.6 & 1 & 76.6 \\
\hline \multicolumn{5}{r}{ Mean score } & 52.97 & 1589.1 \\
\hline
\end{tabular}

The table above shows the highest score is 76.6 which is categorized as good and the lowest score is 33.3 which is categorized as poor classification while the range of the students' score is $\mathbf{4 3 . 3}$. The mean score is $\mathbf{5 2 . 9 7}$ that is classified as fair. It is obvious that the students' understanding is fair.

\section{The distribution of the students' classifications.}

Table 2. The distribution of the classification

\begin{tabular}{rlrr}
\hline No & Classifications & Number of students & Percentage (\%) \\
\hline 1 & very good & 0 & 0.0 \\
2 & good & 7 & 23.3 \\
3 & fair & 20 & 66.7 \\
4 & poor & 3 & 10.0 \\
5 & very poor & 0 & 0.0 \\
\hline & total & 30 & 100.0 \\
\hline
\end{tabular}

It is clear that most of the students are in fair classification with the percentage $66.7 \%$. It shows that most of the students are in fair range in understanding the vocabularies of American and British English. In this case the understanding of the synonym of the English varieties of American and British English.

\section{Discussion}

Discussing about the students' understanding of American and British English, they are included into fair classification. It is based on the mean score that is tabulated by the simple 
statistic. The speculations are concerned to the unfamiliar words. They might not have exposed some words that were not familiar for them such as trunk, lorry, or aerial as they never use those words in their daily life. But indeed it reflects that the students have fair understanding toward the differences between American and British English vocabulary.

Biswanger (2008: 43-44) concluded that varieties of English are still not adequately represented in current ELT. It means that varieties of English might be not taught explicitly. The curricula, material, and teacher training program have concerned certain details. If we relate the data found with this statement the students' understanding vocabulary of American English and British English may have been influenced by inadequate exposure of certain feature of the English varieties differences. They may only use one variety so it is hard to match the similar words or synonyms among both varieties. Beside that English is not second language in Indonesia so it is rather difficult to have more exposure between both of the varieties. Somehow the students of language education program should have good understanding in both varieties as many books may be written in British. Knowing only one variety may be bothering them in significant difference. As Tottie in Alftberg (2009:4) stated that the text-books are used in schools in many countries in many countries today are still mostly British English-oriented.

Above all the students need to expose both varieties of English. The most important is that the students should be able to identify the differences between both varieties. In this case the students can differentiate by the pronunciation, grammar, vocabulary, and spelling. Indeed Safaa (2015:23) explained that British and American English have variants of English as a whole: the differences do not only affect the pronunciation but also other levels like grammar, writing, semantics and lexics. It means that the students need to expose both of the varieties and it is useful to learn the differences of American and British English.

It can be concluded that the students' vocabulary understanding of American and British English is fair it can be seen by the mean score that is 52.9 which is classified into fair classification. It seems that the students need more exposure of the differences between American and British English. For the implication the lecturers need to make the students notice more about the differences of English variety features to maximize the students' competence in communicating in English.

\section{Conclusion}

The lecturers need to make the students notice more about the differences of English variety. In this case it is related to vocabulary. At least the material can make the students expose the differences of vocabulary in both varieties. For the next research, the implementation of teaching American and British English can be considered to improve the students' understanding.

\section{References}

Alftberg, A. (2009). British or American English? Attitudes, Awareness and Usage. Retrieved on $28^{\text {th }}$ August 2018.

Biswanger, M. (2008). Varieties of English in Current Language Teaching. Stellenbosch Papers in Linguistics, 38. 27-47. https://doi.org// 0.5574/38-0-2 I

Crystal, D. (2003). English as A Global Language. New York: Cambridge University Press Farrel, T. \& Martin, S. (2009). To Teach Standard English or World Englishes? A balanced Approach to Instruction. English Teaching Forum, 2

Jendra, M. (20I0). Ragam Bahasa Inggris. Graha IImu 
Marliani. (20I4). Using Personal Vocabulary Notes (PVN) Technique to Develop Students' Vocabulary at SMA Negeri 2 Palopo. Unpublished Thesis. Universitas Cokroaminoto Palopo

Stelzerova, P. (20I4). Teaching Differences between British and American English in LowerSecondary EFL Classes. Prague: Charles University

Safaa, A. (20I5). British vs American English for University Students Teaching Purposes: the Case of Third-Year EFL Students at Tlemcen University. 